\title{
The Effect of Certification and Motivation on Teacher Performance
}

\author{
Firdaus Akbar ${ }^{1 *}$, Yasir Arafat ${ }^{2}$, Syaiful Eddy ${ }^{2}$ \\ ${ }^{I}$ SMPN 1 Sungai Lilin \\ ${ }^{2}$ Universitas PGRI Palembang \\ *Corresponding author.Email: firdaus.akbar666@gmail.com
}

\begin{abstract}
The objective of this study was to determine the impact of teacher certification and motivation on teacher performance at SMP Negeri 1 Sungai Lilin. The sample size of all SMP Negeri 1 Sungai Lilin teachers was 20. Sampling technique was saturated, i.e. where the respondents who were taken were all the teachers who were sampled by the research population. Data were collected by distributing questionnaires using the Likert 5-point scale to measure 69 items of the statement. The method of analysis used is a multiple linear regression analysis. The findings have shown that both the certification of the teacher and the encouragement of the teacher have had a substantial effect on the success of the teacher. Second, the certification of teachers has a partial and important influence on the success of teachers. Third, the motivation of teachers has a partial and important influence on the performance of teachers.
\end{abstract}

Keywords: Teacher Certification, Teacher Motivation, Teacher Performance

\section{INTRODUCTION}

The aim of the National Education Standards is to preserve the quality of national education with a view to educating the country and forming the character and civilization of the nation with dignity. To achieve this aim, the Government sets out eight criteria to be considered in the implementation of the educational process, namely content standards, process standards, competency standards for graduates, standards for educators and personnel, standards for services and equipment, standards for management, funding standards and standards for educational evaluation.

The quality of national education is closely linked to educators/teachers. Teachers have expertise as well as essential roles for leading, guiding and assessing students in early childhood education in formal education and higher school [1].

The development of a nation is highly dependent on educational factors, as learning represents an increasingly role in improving the quality of education of human resources (HR), which is an important element in the development of a nation. Quality education can produce high-quality and productive human capital [2]. Quality human capital are the cornerstone of the growth of the country.

The level of success of a teacher in performing educational tasks on the basis of responsibilities based on established work standards to achieve educational objectives is called teacher performance [3]. The teacher must therefore have four competencies, in accordance with the Regulation of the Minister of National Education No. 16 of 2007 [4], with regard to qualifications and competencies, i.e. pedagogical competence, personality competence, professional competence and social competence. Of the four competencies that the teacher must have, there may be a description of the performance of the teacher in the performance of his duties.

Following the promulgation of Law No. 14 of 2005 on Teachers and Educators, qualification has become a common concept and has become a hot topic of discussion for most people, especially in the world of education. It turns out that certification is a new phenomenon, and the term is said to concern the fate and future of teachers.

The enacted law has three functions, namely as a legal basis for teachers through arbitrary actions by 
students, parents and society, and to improve the professionalism of teachers and the welfare of teachers [5].

Teacher certification is therefore a promising program for teachers. The Government intends to improve the performance and living standards of teachers. Of course, this good news is warmly welcomed by educators and educational staff. This hope will be realized after the government issued Permendiknas Number 18 of 2007 on Teacher Certification in Occupation, 4 May 2007 [6].

In addition, there are educational actors who do a variety of ways to obtain educational certificates that benefit themselves. When conducting the pre-analysis relationship, the researcher noted that there were several educators who had obtained certification, but their work was inadequate, for example, there were several educators who had obtained certification when they arrived at educational institutions above 07.10 WIB, there were also educators who had been certified, who did not prepare for regular training. With this research, the researcher wants to show that there are, in fact, educators/teachers who have been certified but are unable to advance their work to the level of expertise required by the regulations on educators/teachers and professors. Zulkifli et al [7] states that enthusiasm for work and certification play an important role in enhancing the well-being and efficiency of teachers.

\section{METHODS}

This methodology is quantitative study, that is, research [8] which focuses on the study of objective phenomena to be experimentally analyzed. Quantitative analysis is a method that uses data in the form of numbers as a way to interpret knowledge about what you want to know. The analysis uses a lot of numbers, starting with data collection, data interpretation and the display of research results. The information shown in this analysis are descriptive statistics, namely interview questionnaire data. The study consists of two independent variables, namely teacher certification $\left(\mathrm{X}_{1}\right)$, teacher motivation $\left(\mathrm{X}_{2}\right)$, while the dependent variable is teacher performance $(\mathrm{Y})$.

Quantitative approach analysis has been performed. This research approach uses partial and parallel regression methods used for analysis or hypothesis testing if the researcher wants to know the effect or relationship of the independent variable to the dependent variable, where one of the independent variables is regulated (made permanent) by Musfiqon [9] ex post-facto research design is a research that aims to investigate events that have occurred. The population in this study was all educators at SMP Negeri 1 Sungai Lilin, which consisted of 20 teachers. Sampling was carried out by the researcher using a saturated sampling technique, namely a sampling technique that took up the entire amount of population [9].

Collection of data techniques in this study was carried out using questionnaires, interviews, findings or observations, examinations or tests, documentation and so on [10]. In addition, Sugiyono [11] state that data collection techniques can be carried out through interviewing, questionnaires, observations and a combination of the three. In this study, the data collection technique used by the researcher was a questionnaire to be answered by the respondent on the basis of the situation, observation and documentation they experienced. Data collected by using the Likert scale model. The analytics methodology used simple regression and multiple regression analysis with SPSS For Windows version 25.0.

\section{RESULTS AND DISCUSSION}

1) Impact of teacher certification on the performance of teachers

The relationship between teacher qualification and teacher success is represented in the form of the $\mathrm{Y}$ regression equation $\mathrm{Y}=31.691+0.649 \mathrm{X}_{1}$. The graphical method for the dependent variable can be seen in the table below.

Table 1. Significance of the influence of teacher certification on teacher performance

\begin{tabular}{|c|c|c|c|c|c|}
\hline \multirow[b]{3}{*}{ Model } & \multicolumn{3}{|c|}{ Coefficients } & & \\
\hline & $\begin{array}{r}\text { Uns } \\
\text { zed Coe }\end{array}$ & $\begin{array}{l}\text { andardi } \\
\text { fficients }\end{array}$ & $\begin{array}{l}\quad \text { Standard } \\
\text { ized } \\
\text { Coefficients }\end{array}$ & & \\
\hline & B & $\begin{array}{l}\mathrm{S} . \\
\text { Error }\end{array}$ & Beta & $\mathrm{t}$ & ig. \\
\hline t) (Constan & $691^{31 .}$ & $808^{17 .}$ & & 780 & $092^{0 .}$ \\
\hline $\begin{array}{l}\text { Certifica } \\
\text { tion }\end{array}$ & $49^{0.6}$ & $61^{0.1}$ & 0.690 & $040^{4 .}$ & $001^{0 .}$ \\
\hline
\end{tabular}

a. Dependent Variable: Teacher Performance 
Centered on the importance test of the teacher qualification component for the success of the teacher at SMP Negeri 1 Sungai Lilin, the $t$ value was 4.040> the $t$ table price was 1.9944 If the $t$ value was greater than the $\mathrm{t}$ table and the significance value was 0.001 less than 0.05 . Then Hol is approved in such a way that there is a major impact on the success of teacher certification at SMP Negeri 1 Sungai Lilin.

Certification is essentially about restoring and enhancing the quality of teachers/educators as well as learning administration. In addition, the meaning of performance is a description of how learning is carried out and the responsibility to maximize the work of the educator in the conduct of learning activities. In the context of the comfort of educators, which is supported by the existence of this certification, it is more important for an educator to advance their work. Certification may also be referred to as an incentive for educators to be qualified and competent in the training of students.

The process of certification for professional performance in the performance of teaching duties and functions must be followed by an increase in welfare. Teacher welfare is reflected in the use of earned salaries and incentives. Low teacher welfare in Indonesia can affect the performance of teachers, the spirit of dedication and the development of professionalism [12].

At the same time, the relationship between certification and performance of teachers lies in the educational outcomes given to students who are guided by educators, both lecturers and teachers. Certification which is a certificate to promote the professionalism of educators, intended for educators to further improve their performance by supporting the Government in the education of the nation and the State. This shows that the higher the certification received by the teacher, the higher the performance of the teacher in SMP Negeri 1 Sungai Lilin District, Musi Banyuasin Regency.

On the basis of the discussion alluded to above, it can be seen that the government's qualification is simply intended to enhance the performance of teachers and other educational workers. Looking at the sharing of government decisions that have been made, all of them show a positive direction and have good goals. Qualification of educators has a positive impact on the success of teachers. Educational organizations offering qualifications to teachers would be followed by an improvement in the performance of teachers.

The results of this analysis are consistent with Muslich's theory [5], which notes that certification of teachers is a requirement for improving teacher quality, responding to the globalisation of teacher performance after certification, moving around with the decentralized method, and Hopes to have a big effect on qualified teachers. The quote above demonstrates how certifications are the process for teachers who meet certain criteria to receive educators' certificates and are competent, although the results of the research fit into the category of adequate study, of realizing national education objectives which are followed by an improvement in quality of work and decent welfare.

The impact of full-day schooling and the credential of teachers on the teacher output are connected to these investigations in Trianto and Triwulan [14] are: (1) full day school impacts on the success of junior secondary school teachers in the Kasami District; (2) teacher certification has an effect on the success of teachers; and (3) there is a shared impact on the success of teachers in SMP Negeri Bima District School and Teacher Certification. The variable output of the teacher depends on the variable full day-school and the teacher qualification. The variable output of the teacher depends on the variable complete day-school and the qualification of the teacher, depending on the impact of the coefficient of determination. In addition, other factors outside of the study variables affect it.

\section{2) The effect of teacher motivation on teacher performance}

The pattern of relationship between teacher motivation and teacher success is represented in the form of the linear regression $\mathrm{Y}=31.691+0.649 \mathrm{X}_{1}$. The significance test for the regression equation can be seen in the table below.

Table 2. Significance of the influence of teacher motivation on teacher performance

Coefficients

\begin{tabular}{|c|c|c|c|c|c|c|}
\hline \multirow[b]{2}{*}{ Mod } & & \multicolumn{2}{|c|}{$\begin{array}{c}\text { Unstandardized } \\
\text { Coefficients }\end{array}$} & \multirow{2}{*}{$\begin{array}{c}\text { Standardized } \\
\text { Coefficients } \\
\text { Beta }\end{array}$} & \multirow[b]{2}{*}{$\mathrm{t}$} & \multirow[b]{2}{*}{ Sig. } \\
\hline & & B & $\begin{array}{l}\text { Std. } \\
\text { Error }\end{array}$ & & & \\
\hline \multirow[t]{2}{*}{1} & (Constant) & 23.324 & 19.417 & & 1.201 & 0.245 \\
\hline & $\begin{array}{l}\text { Motiva } \\
\text { tion }\end{array}$ & 0.734 & 0.177 & 0.698 & 4.135 & 0.001 \\
\hline
\end{tabular}

a. Dependent Variable: Teacher Performance 
Centered on the assessment of the teacher motivation variable on the results of the teacher at SMP Negeri 1 Sungai Lilin, the $t$ value was 4.135> the $t$ table price was 1.9944 where the $t$ value was greater than the $t$ table and the significance value was 0.001 less than 0.05 , Ho1 agreed that there was a major effect on the output of the instructor at SMP Negeri 1 on the motivation of the teacher.

Motivation to work is a condition which influences and guides the teachers' conduct or desire to work or to take part in school activities. Two factors, namely internal and external factors, influence work motivation. The internal considerations include economic necessities, successes, obligations and appreciation. Outside factors include salary pay, leadership and employee relationships. To satisfy all of his needs, a teacher needs to meet these drivers, so he has high motivation for work. The instructor works well with high job motivation such that the teacher performs exceptionally.

The results of this paper are not consistent with Robbins' theory et al. [15], which describes motivation as a mechanism in which attempts to gain a sense of duty are energized, guided and sustained, in such a manner that they are more disciplined in carrying out their work by the results of research obtained in the wrong category. This is consistent with Siti Umami et al's study. It can be inferred from the results of the analysis: 1) leadership has an effect on SMP Negeri 1 Tanjung Raja's teacher discipline; 2) teacher encouragement in the SMP Negeri 1 Tanjung Raja job discipline; 3 ) the inspiration for leadership and teacher work at SMP Negeri 1 Tanjung Raja together in the area of teacher work [16].

\section{3) The effect of teacher certification and encouragement on teacher performance}

The relationship model for teaching courses and teacher motivation for teacher success is expressed in the form of the regression equation $\mathrm{Y}=12.279+$ $0.379 \mathrm{X}_{1}+0.450 \mathrm{X}_{2}$. This means that the performance of teachers would see a positive improvement in teacher certification and motivation.

Table 3.

Multiple regression summary model

\begin{tabular}{lrrrr}
\hline Model & R & R Square & $\begin{array}{c}\text { Adjusted R } \\
\text { Square }\end{array}$ & $\begin{array}{c}\text { Std. Error of the } \\
\text { Estimate }\end{array}$ \\
\hline 1 & $.760^{\mathrm{a}}$ & 0.577 & 0.528 & 6.02199
\end{tabular}

a. Predictors: (Constant), Motivation, Certification

In attempt to figure out the facts of the hypotheses tests, a parallel testing was conducted out using the $\mathrm{F}$ test to assess the effect of school culture variables and organizational engagement on teacher results. The evaluation parameters are as follows: a) if the probability value (significant) is $<0.005$, then $\mathrm{Ho} 3$ is refused, and $b$ ) if the probability value (significant) is $>0.005$, then Ho3 is accepted. The test conditions are as follows for the F test: (a) Ha3 is accepted if you have F count $>\mathrm{F}$ table, and (b) Ho3 is accepted if $\mathrm{F}$ count $\leqslant \mathrm{F}$ table is accepted.

Based on the test of value of the variable qualification of the teacher and the encouragement of the teacher, along with the success of the teacher. at SMP Negeri 1 Sungai Lilin, it was found that the f value was $11.613>$ the $\mathrm{f}$ table price was 3.13 where the calculated $f$ value was greater than the $f$ table value. And the value was 0.001 which is less than 0.005 than Ho3, so that there is a major impact at the same time between teacher certification and teacher motivation on the success of SMP 1 Sungai Lilin. To figure out what effect the regression coefficient has on the regression model, you can see it simultaneously in the description model table below.

Table 4. ANOVA multiple regression

\begin{tabular}{|c|c|c|c|c|c|c|}
\hline Model & & $\begin{array}{l}\text { Sum of } \\
\text { Squares }\end{array}$ & df & $\begin{array}{c}\text { Mean } \\
\text { Square }\end{array}$ & $\mathrm{F}$ & Sig. \\
\hline \multirow[t]{3}{*}{1} & Regression & 842.307 & 2 & 421.153 & 11.613 & $.001^{\mathrm{b}}$ \\
\hline & Residual & 616.493 & 17 & 36.264 & & \\
\hline & Total & 1458.800 & 19 & & & \\
\hline
\end{tabular}

a. Dependent Variable: Performance

b. Predictors: (Constant), Certification, motivation 
The table above indicates the value of $\mathrm{R}$ that is a sign of the value of the correlation coefficient. The value above the value of the correlation shall be 0.760 . This value can be taken to imply that the relationship between the two study variables is in a strong category. This table also indicates the cost of the square $\mathrm{R}$ or the correlation coefficient (KD) which shows how well the regression model is generated by the interaction of the independent variables and the dependent variable. The $\mathrm{KD}$ measured value is 0.577 that can be interpreted to mean that the independent variable $\mathrm{X}$ has a contribution effect of $57.7 \%$ on variable $Y$ and 33.3 , while the other percent is influenced by factors other than variable $\mathrm{X}$.

This shows that if the certification of teachers is carried out correctly and is accompanied by good objectives, then in the future the work of teachers/educators can be advanced in order to become more qualified. This table even indicates the cost of the square $\mathrm{R}$ or the coefficient of determination (KD) which shows how well the linear regression is generated by the interaction of the independent variables and the dependent variable.

The leader of an educational organization must have a certain approach to inspire educators and educational workers in his/her working environment. It is also encouraging to encourage teachers to earn certification so that teachers are better qualified to get a teacher's recognition and profits. This has to do with the study of Fatiah. This study was carried out in 2013 at SMA Negeri 5 Surakarta. This analysis is a quantitative study using comparative causal or post-facto research methods. It can be concluded on the basis of data analysis and debate that: (1) teacher certification at SMA N 5 Surakarta has a positive impact on teacher performance; (2) The motivation for teaching work in SMA N 5 Surakarta has a positive impact on teaching results. (3) The certification and encouragement for teacher work in teachers is having a positive impact on SMA N 5 Surakarta's teacher results. [17].

This study is in line with and in conjunction with Fenti et al research. The findings have shown (1) that qualification of teachers and encouragement for work have a positive impact on teacher work; (2) certification of teachers has a great effect on the performance of teachers, and 3) enthusiasm for work has a significant effect on firm performance of teachers[18]. Based on the results of the evaluation process there must be improvements to the assessment process, this is intended that the product obtained is in line with expectations [19].

\section{CONCLUSION}

On the basis of the findings of the data analysis, the impact of qualification and job motivation on performance, both partially and concurrently, can be explained as follows: 1) this certification has a partial effect on performance, so that it can be inferred that the first hypothesis is acknowledged. On the basis of the test results, it can be seen that the certification variable has a regression coefficient value of 0.001 and $t$ value of 4.040. Meanwhile, the significance level is lower than the specified significance level, i.e. $0.001<0.05$. This indicates that qualification has a partial and important effect on performance; 2) that motivation influences the performance of the instructor in part, so that it can be assumed that the first hypothesis is dismissed. Based on the test results, it can be shown that the motivation variable has a regression coefficient of 0.245 and a t-count value of 4.135 . Although the value of the $t$ table is 2.085 , the value of the $t$ count $<t$ table is less than the defined value, i.e. $0.001<0.05$. This shows that motivation affects success in part and significantly.

\section{AUTHORS' CONTRIBUTION}

Firdaus Akbar: designed and performed experiments and analysed data.

\section{ACKNOWLEDGMENTS}

Our deepest gratitude goes to Teachers in SMP Negeri 1 Sungai Lilin, Chancellor of Palembang PGRI University, Director of the Postgraduate Program of PGRI Palembang University and the Education Management Study Program of PGRI Palembang University, who have supported us in doing this extraordinary thing. This project is funded independently. We also want to thank our Education Management friends who helped us a lot in a short time frame to complete this project.

\section{REFERENCES}

[1] Undang-undang RI Tahun 2005 [Republic of Indonesia Law of 2005].

[2] Aleksius, M., \& Jailani. (2013). Hubungan Kepemimpinan Kepala Sekolah, Motivasi Kerja, dan Komunikasi Interpersonal dengan Kinerja Guru Matematika SMA [The Relationship between Principal Leadership, Work Motivation, and Interpersonal Communication with the Performance of High School Mathematics Teachers]. PYTHAGORAS: Jurnal Pendidikan Matematika vol. 8, no. 1, pp. 12-20.

[3] Barnawi \& Arifin, M. (2014). Kinerja guru profesional [Professional teacher performance]. Yogyakarta: Ar-Ruzz.

[4] Permendiknas no 16 tahun 2007

[5] Muslich. (2007). Sertifikasi Guru [Teacher Certification]. Bandung: Rosda Karya. 
[6] Permendiknas No 18 tahun 2007

[7] Zulkifli, M., Arif, D., \& Sutrisno, E. (2013), Motifasi Kerja, Setifikasi, kesejahteraan dan kinerja Guru [Work Motivation, Certification, welfare and teacher performance]. Persona: Jurnal Psikologi Indonesia.

[8] Musfiqon, H. M. (2012). Metodologi Penelitian Pendidikan [Educational Research Methodology]. Jakarta: PT Prestasi Pustakaraya.

[9] Sugiyono. (2013). Metode Penelitian Kuantitatif dan $R$ dan D [Quantitative Research Methods and $R$ and $D$ ]. Bandung: Alfabeta.

[10] Arikunto. (2010). Prosedur Penelitian Suatu Pendekatan Praktek [Research Procedure A Practice Approach]. Jakarta: Rineka Cipta.

[11] Sugiyono. (2012). Metode Penelitian Pendidikan: Pendekatan Kuantitatif, Kualitatif, dan $R \& D$ [Educational Research Methods: Quantitative, Qualitative, and $R \& D$ Approaches]. Bandung: Alfabeta.

[12] Tilaar. (2012). Pendidikan Kebudayaan dan Masyarakat Madani Indonesia [Indonesian Culture and Civil Society Education]. Jakarta: Bumi Aksara.

[13] Trianto, T., \& Triwulan, T. (2007). Sertifikasi Guru dan Upaya Peningkatan Kualifikasi, Kompetensi dan Kesejahteraan [Teacher Certification and Efforts to Improve Qualifications, Competence and Welfare]. Jakarta: Prestasi Pustaka.

[14] Utari, A. S., Tobari., \& Puspita, Y. (2020). Pengaruh Full Day School Dan Sertifikasi Guru Terhadap Kinerja Guru [The Influence of Full Day School and Teacher Certification on Teacher Performance]. Jurnal Manajemen, Kepemimpinan, dan Supervisi Pendidikan, 5(2).

[15] Robbins, S. P., \& Coulter, M. (2010). Management. Jakarta: Erlangga.

[16] Umami, S., Lian, B., \& Missriani. (2021). Pengaruh Kepemimpinan Dan Motivasi Kerja Guru Terhadap Disiplin Kerja [The Effect of Leadership and Teacher Work Motivation on Work Discipline]. Jurnal Manajemen, Kepemimpinan, dan Supervisi Pendidik., vol. 6, no. 1.

[17] Fatiah. (2018). Pengaruh Sertifikasi Guru Dan Motivasi Kerja Guru Terhadap Kinerja Guru SMAN 5 Surakarta [The Effect of Teacher Certification and Teacher Work Motivation on Teacher Performance at SMAN 5 Surakarta]. Jupe UNS, 2(1).
[18] Fenty, Harapan, E., \& Destiniar. (2021). Pengaruh Sertifikasi Guru Dan Motivasi Kerja Terhadap Kinerja Guru [The Effect of Teacher Certification and Work Motivation on Teacher Performance]. Jurnal Manajemen, Kepemimpinan, dan Supervisi Pendidik., vol. 6, no. 1 .

[19] Areli, A. J., Lian, B., \& Kristiawan, M. (2020). An Evaluation of Implementation Industrial Work Practice Programs in Vocational School. International Journal of Progressive Sciences and Technologies (IJPSAT), 20(2), 179-186. 